Miami Nature Biotechnology Short Reports

TheScientificWorld (2001) 1 (S3), 61SR

ISSN 1532-2246; DOI 10.1100/tsw.2001.190

\title{
SEQUENTIAL EVENTS DURING NUCLEAR APOPTOSIS
}

\author{
Madeleine Kihlmark, Gabriela Imreh, and Einar Hallberg* \\ Södertörns Högskola (University College), Box 4101, 14104 Huddinge, Sweden \\ *Einar.Hallberg@sh.se
}

INTRODUCTION. Nuclear apoptosis is characterized by condensation and fragmentation of chromatin and disruption of the nuclear pores, membranes and lamina $(1,2)$. We have investigated the sequential degradation of proteins from the nuclear envelope and correlated it to other hallmarks of apoptosis such as chromatin condensation, DNA fragmentation and nuclear pore clustering.

METHOD. Monolayer BRL cell cultures were treated with $0.5 \mu \mathrm{M}$ staurosporine to induce programmed cell death. Degradation of nuclear envelope proteins was studied by immunofluorescence microscopy, confocal microscopy and Western blotting. DNA fragmentation was monitored using the TUNEL assay.

RESULTS. By Western blotting and pairwise comparison of double labeling immunofluorescence microscopy of BRL cells undergoing apoptosis we demonstrate that during apoptosis proteins of the nuclear envelope disappear in a specific order. POM121 (an integral pore membrane protein) and RanBP2 (a component of the cytoplasmic filaments of the NPC) disappeared first, followed by NUP153 (a component of the nucleoplasmic basket) and lamin B, whereas p62 (centrally located in the nuclear pore) remained throughout the experiments. The apoptotic degradation of proteins from the nuclear envelope could be totally prevented by a caspase inhibitor.

DISCUSSION. Our data suggests a specific order of events during nuclear apoptosis, summarized in Fig. 1. Condensation of chromatin occurs before DNA fragmentation, degradation of nuclear envelope proteins and disruption of the nuclear membranes. Degradation of POM121 and RanBP2 started before DNA fragmentation could be detected. At a later step NUP153 and lamin B was degraded concomitant with onset of DNA fragmentation. Degradation of NUP153 and lamin B correlated with disruption of the nuclear periphery and clustering of nuclear pores. 


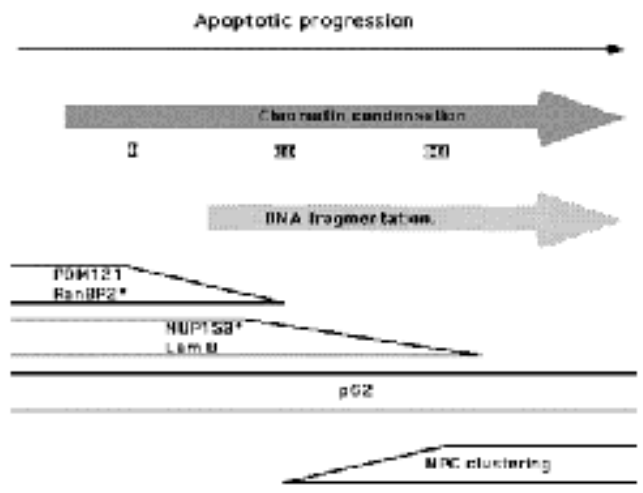

ACKNOWLEDGEMENT. Supported by the Swedish National Board for Laboratory Animals.

\section{REFERENCES.}

1. Wyllie, A.H., Kerr, J.F.R., and Currie, A.R. (1980) Int. Rev. Cytol. 68, 251-305

2. $\quad$ Lazebnik, Y.A., Cole, S., Cooke, C.A., Nelson, W.G., and Earnshaw, W.C. (1993) J. Cell Biol. 123(1), 7-22 

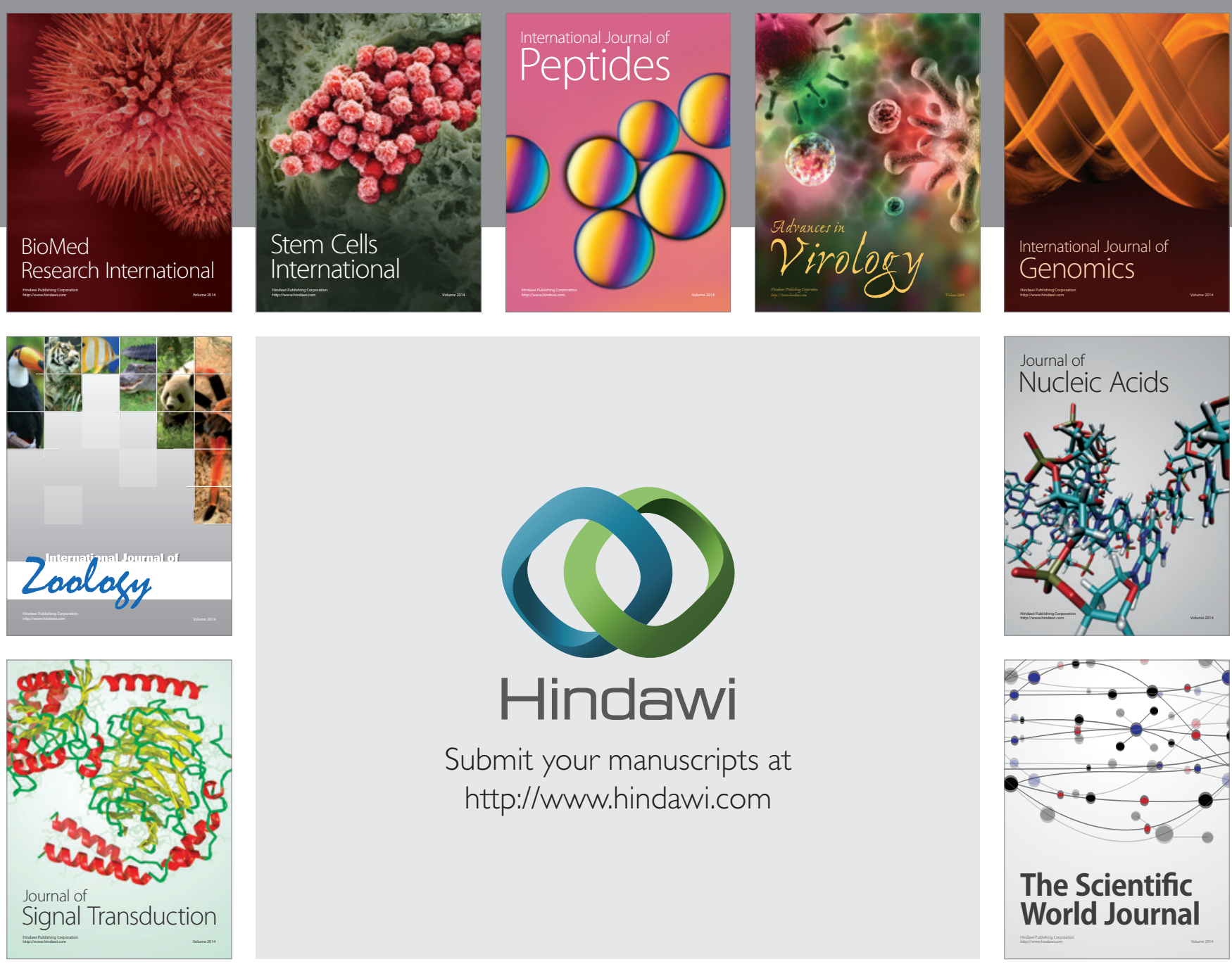

Submit your manuscripts at

http://www.hindawi.com
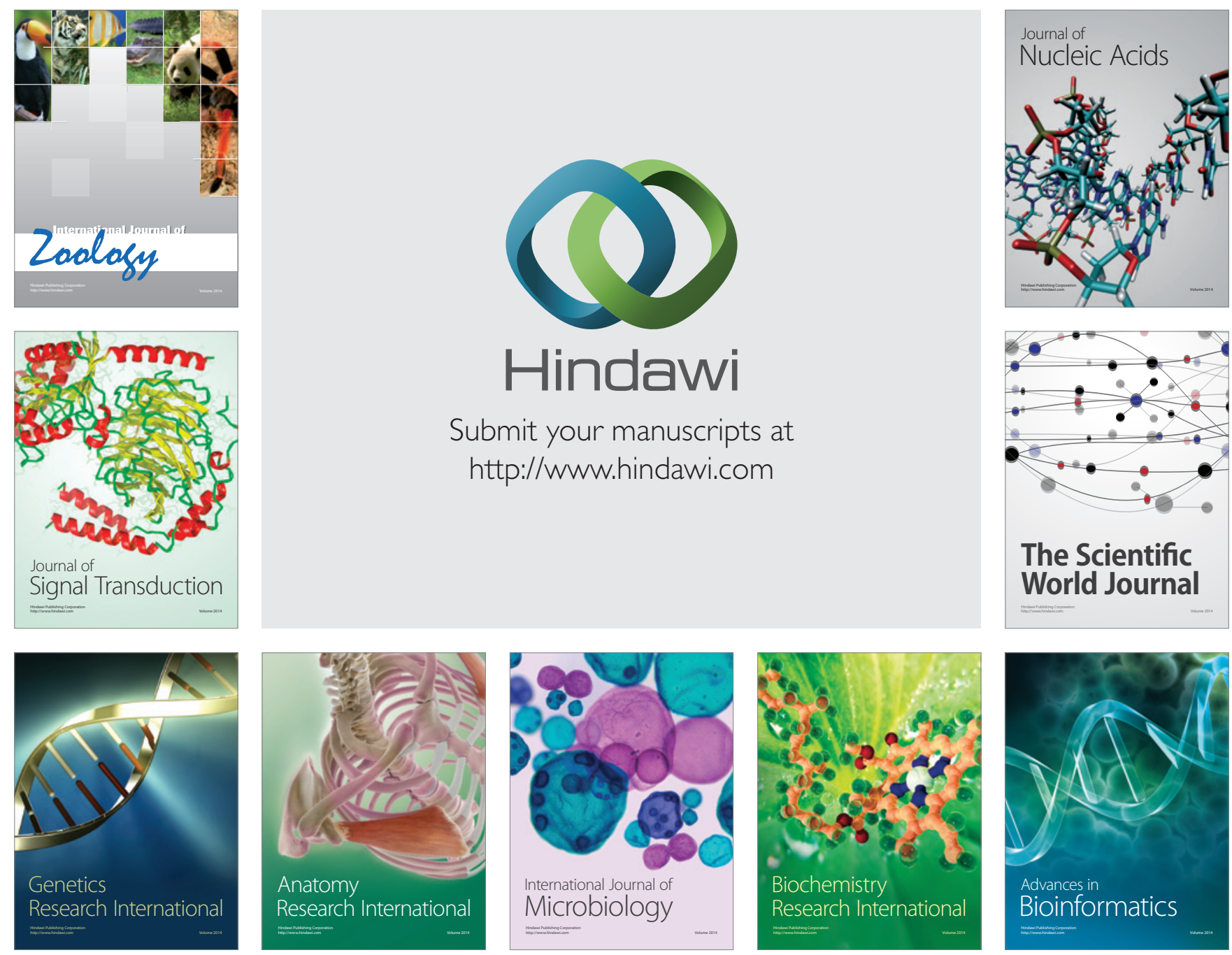

The Scientific World Journal
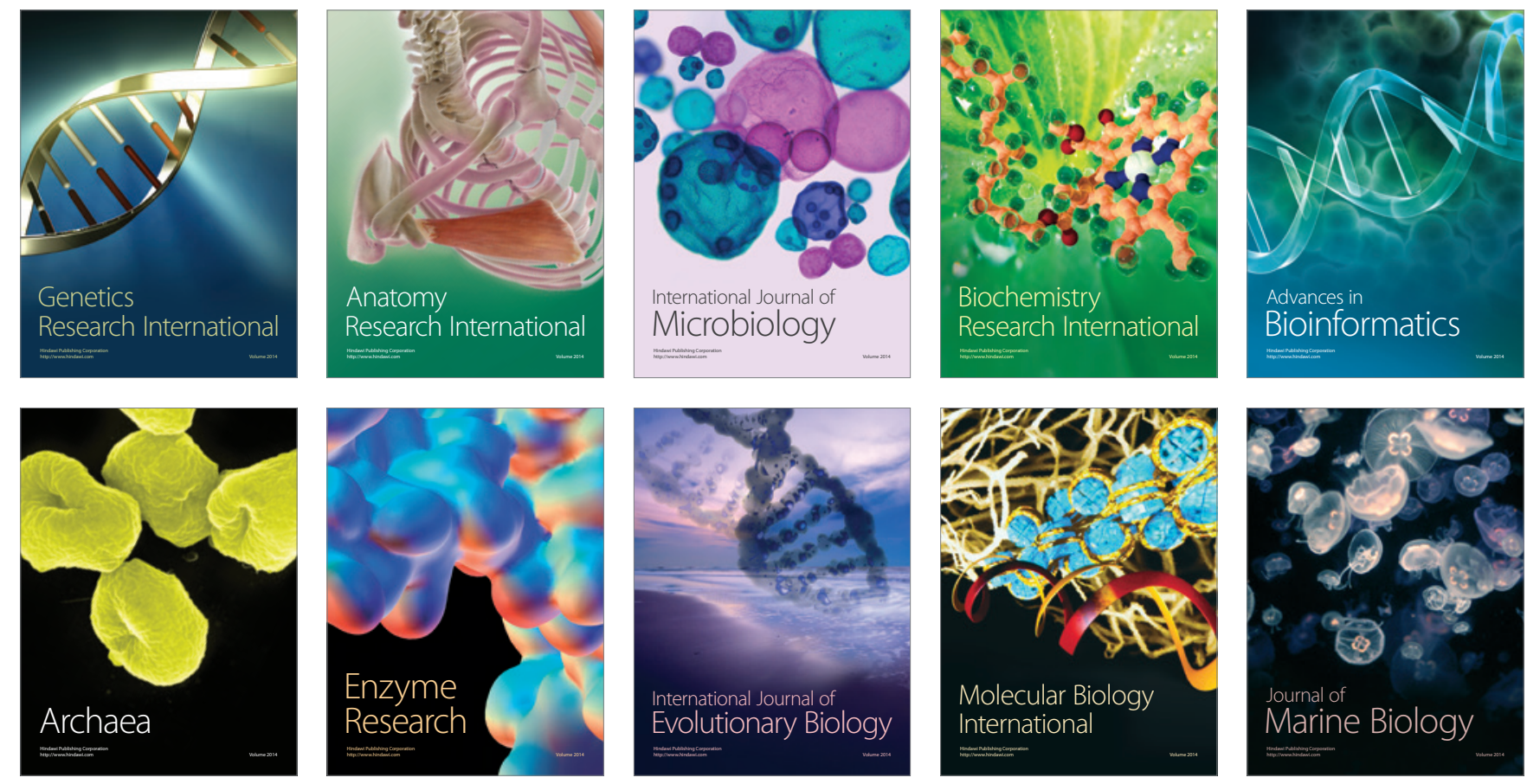